\title{
The effect of different dietary fibres on short-chain fatty acid concentrations in the caecum and lipid profile in pig serum
}

\author{
I. Furgal-Dicrżuk \\ National Rescarch Institute of Animal Production, \\ Department of Animal Nutrition \\ 32-083 Balice, Poland
}

\begin{abstract}
The hypolipidemic effect of adding different types of dietary fibre (Arbocel R, Vitacel AF, guar gum) to diets for growing- finishing pigs was evaluated on 24 animals. The best results in lowering total serum cholesterol and serum triacylglycerols ( 2.40 and $0.69 \mathrm{mmol} / \mathrm{l}$, respectively) were obtained in the group with guar gum. In this group, caecal propionic acid production was significantly higher (43.5 $\mu \mathrm{mol} / \mathrm{g}$ of caecal content) when compared with the groups given Arbocel $R$ and Vitacel Al:
\end{abstract}

KEY WORDS: pig, dietary fibre, serum cholesterol, caecum, short-chain fatty acids

\section{INTRODUCTION}

The mechanism of hypocholesterolemic action of dietary fibre is not clear, although many hypotheses have been proposed by $\Lambda$ nderson et al. (1990). The hypocholesterolemic effect of different types of fibre could be due to their digesta viscosity, which inhibits the absorption of neutral and acid steroids from the small intestine (Anderson et al., 1990). Viscous fibres such as pectin, psyllium, guar gum, arabic gum have been shown to reduce serum cholesterol (Al-Othman et al., 1998; Sudheesh et al., 1999; Levrat-Verny ct al., 2000; Romero et al., 2002) in comparison with insoluble nonviscous fibres such as cellulose (Al-Othman et al., 1998; Romero et al., 2002). Soluble fibres are more easily fermented in the large intestine to short-chain fatty acids (SCFA) as compared with cellulose. The hypothesis that SCFA, especially propionic acid, may lower hepatic cholesterol synthesis has been investigated by Demigne et al. (1995). The aim of this study was to evaluate the influence of different dietary fibres on production of SCFA in the caecum of pigs and their hypolipidemic effect.

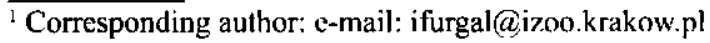




\section{MATERIAL AND METHODS}

The experiment was performed on 24 growing-finishing pigs (Landrace $\times$ Large White sows mated to a Duroc $\times$ Pietrain) from 60 to $110 \mathrm{~kg}$ body weight. The animals were divided into 3 groups of 8 ( 4 barrows and 4 gilts) and housed individually in steel cages, feed and water were provided ad libitum. The basal diet contained, $\%$ : ground barley 50.76 , ground triticale 24.5 , soyabean meal 17 , rapeseed oil 2, L-lysine 0.04, Lutamix PT-2 0.5, NaCl 0.2, dicalcium phosphate 1.2 , fodder limestone 0.3 . The diet was isoenergetic, isoproteinous and isofibrous (12.8 MJ of ME, $16 \%$ crude protein, $4 \%$ crude fibre; $\Lambda O \Lambda C, 1990$ ). $3.5 \%$ of one of the following kinds of fibre were added to the basal diet: Arbocel R (cellulose+lignin; J. Rettenmaier and Söhne GMBH + CO Germany), Vitacel AF (cellulose+apple pectin; J. Rettenmaier and Söhne GMBH + CO Germany), guar gum (Trademark of Habgen Guars Lid.).

At the end of the experiment all of the pigs were slaughtered. Blood samples for estimation of lipid level were taken from the jugular vein and serum samples were separated $(1500 \mathrm{~g} \times 15 \mathrm{~min})$. The caecal content was transferred to microfuge tubes, preserved with $25 \%$ meta-phosphoric acid and immediately frozen at $-20^{\circ} \mathrm{C}$. Total cholesterol (TC), high-density lipoprotein fraction cholesterol (HDL-C), and triacylglycerols (TAG) were analysed enzymatically in serum with Pointe Scientific kits. The cholesterol in the low-density lipoprotein fraction (LDL-C) was calculated as LDL-C = TC - HDL-C - TAG/5. The content of SCF $\Lambda$ (propionic, acetic, butyric) in the caecum was measured using a Varian 3400 gas chromatograph (CP-WAX 58 column, $0.53 \mathrm{~mm} \times 25 \mathrm{~m}$ ). The results of the experiment were subjected to statistical two-way analysis of variance and Duncan's multiple range test using Statistica version 5.1.

\section{RESULTS}

The influence of various diets on serum $\mathrm{TC}$ and cholesterol in lipoprotein fractions is given in Table 1 . TC concentrations in serum, LDL-C and TAG level in serum were significantly $(P \leq 0.01)$ lower in the group with guar gum when compared with other groups. This group also had the highest HDL-C:TC ratio $(\mathrm{P} \leq 0.05)$. In groups fed diets with Vitacel AF or Arbocel $\mathrm{R}$, the amounts of propionic acid were similar and significantly lower $(\mathrm{P} \leq 0.01)$ when compared with the guar gum group (Table 1). A negative correlation between caecal propionate production and serum $\mathrm{TC}(\mathrm{r}=-0.55 ; \mathrm{P}<0.01)$ and caecal propionate production and serum TAG $\left(\mathrm{r}^{-}-0.69 ; \mathrm{P}<0.01\right)$ was found. 
TABLF. 1

Scrum lipid and caecum short-chain fatty acid concentrations in pigs fed diets containing various kinds of fibre

\begin{tabular}{|c|c|c|c|c|c|c|c|}
\hline \multirow[b]{2}{*}{ Item } & \multicolumn{3}{|c|}{ Dietary fibre (DF) } & \multicolumn{2}{|c|}{$\operatorname{Sex}(S)$} & \multirow[b]{2}{*}{ SEM } & \multirow[b]{2}{*}{$\mathrm{DF} \times \mathrm{S}$} \\
\hline & $\begin{array}{c}\text { Arbocel } \\
\mathrm{R}\end{array}$ & $\begin{array}{l}\text { Vitacel } \\
\wedge \mathrm{F}\end{array}$ & $\begin{array}{l}\text { guar } \\
\text { gum }\end{array}$ & gilts & barrows & & \\
\hline Total cholesterol, $\mathrm{mmol} / \mathrm{L}$ & $2.58^{\mathrm{AB}}$ & $2.71^{\mathrm{B}}$ & $2.40^{\mathrm{A}}$ & 2.58 & 2.55 & 0.04 & ns \\
\hline $\begin{array}{l}\text { Cholesterol in high-density } \\
\text { lipoprotein fraction, } \mathrm{mmol} / \mathrm{L}\end{array}$ & $0.94^{A}$ & $1.06^{\mathrm{B}}$ & $0.96^{\wedge \beta}$ & 0.98 & 0.99 & 0.02 & ns \\
\hline $\begin{array}{l}\text { Cholesterol in low-density } \\
\text { lipoprotein fraction. mmol/L }\end{array}$ & $1.50^{\mathrm{h}}$ & $1.49^{\mathrm{h}}$ & $1.30^{\mathrm{a}}$ & 1.43 & 1.40 & 0.03 & ns \\
\hline $\begin{array}{l}\text { Cholesterol in high-density } \\
\text { lipoprotein fraction: total } \\
\text { cholesterol ratio }\end{array}$ & 0.36 & 0.39 & 0.40 & 0.38 & 0.39 & 0.01 & ns \\
\hline Triacylglycerols, mmol/L & $0.84^{13}$ & $0.82^{\mathrm{B}}$ & $0.69^{\mathrm{t}}$ & 0.80 & 0.77 & 0.02 & $x$ \\
\hline Shorl-chain fatty acid, $\mu \mathrm{mol} / \mathrm{g} \mathrm{c}$ & cum conte & & & & & & \\
\hline acetic & $68.4^{\wedge}$ & $70.0^{\mathrm{Ali}}$ & $79.1^{\mathrm{B}}$ & 71.6 & 73.5 & 1.60 & ns \\
\hline propionic & $31.8^{\wedge}$ & $28.9^{\mathrm{A}}$ & $43.5^{\mathrm{B}}$ & 33.0 & 36.4 & 1.60 & ns \\
\hline butyric & $15.9^{n}$ & $14.6^{\mathrm{A}}$ & $19.8^{\mathrm{B}}$ & 17.2 & 16.5 & 0.60 & ns \\
\hline total SCFA & $120.7^{\wedge}$ & $116.9^{\wedge}$ & $145.5^{\mathrm{B}}$ & 125.5 & 129.9 & 3.10 & ns \\
\hline
\end{tabular}

a.b - values in rows with different letters differ significantly $(P \leq 0.05)$

${ }^{A .13}$ - values in rows with different letters differ significantly $(P \leq 0.01)$

$X-P<0.05$; ns- $P \geq 0.05$

\section{DISCUSSION}

In the present study the decrease in serum TC concentrations $(12 \%)$ in the guar gum group was comparable with the data obtained by Levrat-Verny et al. $(2000)(14 \%)$ and Moriceau et al. (2000) (13\%). The decrease of serum TAG $(20 \%)$ in guar gum-fed animals corresponds with the study by Moundras et al. (1997) $(26 \%)$.

The hypotriacylglycerolemic effect of soluble fibres may be due to increased activity of lipoprotein lipase (LPL) and may be responsible for decreased concentrations of TAG in serum (Sudheesh et al., 1999). Soluble fibres are easily fermented in the large intestine to SCFA when compared with cellulose; the amounts of SCFA in those groups are greater than in diets with cellulose. Propionic acid, in particular, may lower hepatic cholesterol synthesis due to inhibition of HMG-CoA reductase, the rate-limiting enzyme in cholesterol biosynthesis (Demigne et al., 1995). This study demonstrates that propionic acid concentrations were higher $(36 \%)$ in the guar gum group as compared with the Arbocel $\mathrm{R}$ group. 


\section{CONCLUSIONS}

The results of the sludy show that guar gum in the diet decreased scrum TC concentrations and serum TAG in comparison with Arbocel $R$ and Vitacel AF. These results suggest that guar gum could be used as a hypocholesterolemic and hypotriacylglycerolemic'agent in animals.

\section{REFTRENCES}

Al-Othman A., Al-Shagrawi R., Hewedy F., Hamdi M., 1998. Plasma total, lipoprotein cholesterol, organs cholesterol and growth performance in rats fed dictary gum Arabic. Food Chem. 62, 69-72

Anderson J.W., Deakins D.A., Bridge S.R., 1990. Hypocholesterolemic Effects and Proposed Mechanism. Plenum Press Inc., New York, pp. 339-363

AOAC, 1990. Official Methods of Analysis, Association of Official Analytical Chemists. $15^{\text {th }}$ Edition. Arlington, VA

Demigné Ch., Morand C., Levrat M. A., Besson C., Rémésy Ch., 1995. Fffect of propionate on fatty acids and cholesterol synthesis and on acetate metabolism in isolated rat hepatocytes. Brit. J. Nutr. 74, 209-219

Levrat-Verny M. A., Behr S., Mustad V., Rémésy Ch., Demigné Ch., 2000. Low levels of viscous hydrocolloids lower plasma cholesterol in rats primarily by impairing cholesterol absorption. J. Nutr. 130, 243-248

Moriceau S., Besson C.. Levrat M.A., Moundras C., Rémésy Ch., Morand C., Demigné Ch., 2000. Cholesterol-lowering elfects of guar gum: changes in bile acid pools and intestinal reabsorption. Lipids 35, 437-444

Moundras C., Behr S., Rémésy Ch., Demigné Ch., 1997. Fccal losses of sterols and bile acids induced by feeding rats guar gum are due to greater pool size and liver bile acid secretion. J. Nutr. 127, 1068-1076

Romero A., Wcst K., Zern T., Fernandez M., 2002. The seeds from Plantago ovata lower plasma lipids by altering hepatic and bile acid metabolism in guinea pigs. J. Nutr. 132, 1194-1198

Sudheesh S., Vijayalakshmi N.R., 1999. Lipid-lowering action of pectin from Cucumis salivus. Food Chem. 67, 281-286

\section{STRES7C.F.FIIE}

\section{Wplyw różnych rodzajów wlókna pokarmowego na produkcję krótkolańcuchowych kwasów} tluszczowych w jelicie ślepym i profil lipidów we krwi świń

W doświadczeniu przcprowadzonym na 24 tucznikach zbadano hipoholesterolemiczne właściwości różnych rodzajów włókna pokarmowego diety (Arbocel R, Vitacel AF, guma guarowa). Dodatek gumy guarowej do diety istotnie obniżył poziom cholcsterolu calkowitego i triacylglyceroli we krwi (odpowiednio 2.40 i $0.69 \mathrm{mmol} / \mathrm{l}$ ). W tcj grupie zawartość kwasu propionowego w jelicie ślepym była najwyższa $(43,5 \mu \mathrm{mol} / \mathrm{g}$ treści jelita ślepego; $\mathrm{P} \leq 0,01)$ w porównaniu $\mathrm{z}$ grupami $z$ dodatkiem Arbocelu $\mathrm{R}$ i Vitacelu $\Lambda \mathrm{F}$. 